\title{
RECONSIDERING SYLLABIC MINIMALITY IN SPANISH TRUNCATION
}

\author{
ANTONIO GRAU SEMPERE \\ Fairfield University \\ agrausempere@fairfield.edu
}

\begin{abstract}
Resumen
Se sabe que la palabra mínima en español contiene una sola sílaba que domina a dos moras. También se ha demostrado que el pie métrico mínimo en español es monosilábico bimoraico. Así, este estudio sostiene que el tamaño mínimo de los truncamientos en español es igualmente monosílabico bimoraico y ofrece un análisis basado en la Teoría de la Optimidad
\end{abstract}

PALABRAS CLAVE: truncamientos, español, palabra mínima, pie mínimo, Teoría de la Optimidad.

\section{Moraic minimal word in Spanish}

It is well proven that Spanish requires the smallest word to contain no fewer than two moras: rés 'head of cattle', pán 'bread', séd 'thirst', cán 'dog'1. In optimality theoretical terms, FOOTMINo is dominated by PRWD-TO-FT².

\footnotetext{
${ }^{1}$ Examples follow Spanish spelling conventions, except stressed syllables, which are always marked with a stress mark over the vocalic nucleus 'á,' regardless of spelling.

${ }^{2}$ In Optimality Theory (henceforth OT, Prince and Smolensky 1993), unlike other earlier developments in Generative Phonology, there are no rules or derivations. The right output is obtained through the interaction of different components or functions of the grammar: The function GEN(erator) generates for every possible linguistic entry $e$, the group of possible linguistic analyses or candidates (A, B, C...). Furthermore, the function EVAL(autor) evaluates the candidates through a ranking of constraints. The grammar of every language is one possible ordering of the same universal set of constraints, or CON. There are two kinds of OT constraints, markedness constraints, which penalize a certain type of surface structure; and faithfulness constraints, which preserve input-output
} 
(1) PRWD-TO-FT » FoOTMino

a. PRWD-TO-FT (a. k. a. Rooting, Hammond, 1997: 44): a Prosodic Word must dominate at least a foot. (One ${ }^{\star}$ per footless PrWds).

b. FootMin $\sigma$ : feet are minimally disyllabic. (One ${ }^{\star}$ per monomoraic feet).

(2) PRWD-TO-FT » FOOTMINo

\begin{tabular}{|l|c|c|}
\cline { 2 - 3 } \multicolumn{1}{c|}{ Input: $r e s$} & PRWD-TO-FT & FOOTMIN \\
\hline a. $($ rés $)$ & & $*$ \\
\hline b. rés & $\star !$ & \\
\hline
\end{tabular}

Stressed monomoraic examples exist, but are restricted to the following categories (based on Dunlap, 1991: 75):

(3) Spanish monosyllabic monomoraic words

$\begin{array}{lll}\text { a. Functional words: } & \text { á } & \text { 'to' } \\ & d e ́ & \text { 'of } \\ \text { b. Interjections: } & j o ́ & \text { 'whoa!' } \\ & t a ́ & \text { 'beware' } \\ \text { c. Onomatopoeia: } & \text { cló } & \text { 'cluck' } \\ \text { d. Irregular verbs: } & d a ́ & \text { '(s)he gives', imperative 'give' } \\ & d i ́ & \text { 'I gave', imperative 'say' } \\ & v e ́ & \text { '(s)e sees', imperative 'go' } \\ & v i ́ & \text { 'I saw' } \\ & v a ́ & \text { '(s)he goes' } \\ & \text { sé } & \text { 'I know', imperative 'be' } \\ \text { e. Personal pronouns } & y o ́ & \text { 'I' } \\ & \text { tú } & \text { 'you' } \\ \text { f. Other words: } & \text { fé } & \text { 'faith' } \\ & \text { té } & \text { 'tea' } \\ & \text { pré } & \text { 'soldier's daily pay' } \\ & \text { gró } & \text { 'grogram' } \\ & \text { pró } & \text { 'profit' }\end{array}$

or base-truncated form identity. Graphically, OT uses evaluation tableaux. Input and the set of candidates are located at the leftmost vertical column. Constraints are in the top horizontal line divided by a solid line to represent domination. Violations are marked with an asterisk ' '. Fatal violations are marked with '?'. The winner candidate is marked with ' irrelevant since the winner has previously been decided. 
Examples in subsections a-c are non-lexical words and are not subject to minimal word requirements. Only a small number of imperatives and other non-verbs are truly exceptional. According to Dunlap (1991: 75), a search of approximately 70,500 words only yielded a handful of truly monosyllabic monomoraic words and shortenings (gró, pró) in subsection $\mathrm{f}$. In conclusion, despite the existence of a few counterexamples, the hypothesis that the minimal content word in Spanish is bimoraic is solid.

The minimal word in the world's languages is usually a foot (Kager, 1999: 144, but see Crowhurst, 1991/2). Accordingly, it has been proposed for Spanish that the minimal word is a bimoraic monosyllable (among others, Dunlap, 1994). However, as seen above, monomoraic minimal content words are possible in Spanish. Any monosyllabic content word forms a foot, and consequently a PrWd, regardless of its weight.

The hypothesis that all Spanish content words are stressed implies that even light monosyllabic prosodic words build a foot. The claim this study supports is that this behavior is the result of PRWD-TO-FT, and MAX and DEP constraints outranking FOOTMIN $\mu$.

(4) PrWD-TO-FT » FOOTMin $\mu$

FOOTMIN $\mu$ : feet are minimally bimoraic. (One ${ }^{*}$ per monomoraic feet)

A monomoraic word like Spanish té is put under the scrutiny of the previous ranking.

(5) PRWD-TO-FT » FOOTMin $\mu$

\begin{tabular}{|l|c|c|}
\cline { 2 - 3 } \multicolumn{1}{c|}{ Input: $t e$} & PRWD-TO-FT & FOOTMINM \\
\hline a. $\left(t \dot{e}_{\mu}\right)$ & & $*$ \\
\hline b. $t \dot{e}_{\mu}$ & $* !$ & \\
\hline
\end{tabular}

Spanish offers no evidence of vowel lengthening to satisfy minimal word requirements as in Italian (D'Imperio and Rosenthall, 1999). A highly ranked constraint such as NOLONGVOWELS would eliminate surface sub optimal long vowels in this language. The next ranking is responsible for this pattern.

(6) NoLONGVOWELS » FoOtMin $\mu$

NOLONGVOWELS (Rossenthall, 1994: 15): vowels are only dominated by one mora. (One * per long vowel).

We can see the effects of the previous ranking in the next tableau. 
(7) NoLONGVOWELS » FOOTMIN $\mu$

\begin{tabular}{|l|c|c|}
\cline { 2 - 3 } \multicolumn{1}{c|}{ Input: $t e$} & NoLONGVOWELS & FOOTMIN $\mu$ \\
\hline a. $\left(t \dot{e}_{\mu}\right)$ & & $*$ \\
\hline b. $t \dot{e}_{\mu \mu}$ & $* !$ & \\
\hline
\end{tabular}

Dep constraints penalizing segmental epenthesis are also needed to account for candidates that add an additional syllable to comply with FoOTMiNo. DEP IO V disallows the addition of vowels, while Dep IO C does not tolerate the epenthesis of consonants. These constraints crucially dominate FoOTMin $\sigma$ and FoOTMin $\mu$.

(8) DeP IO C, DEP IO V » FOOTMIN $\mu$

a. DEP IO C: output consonants must have input correspondents. (One * per every output consonant without an input correspondent).

b. DEP IO V: output vowels must have input correspondents. (One * per every output vowel without an input correspondent).

(9) Dep IO C, Dep IO V » FootMins, FootMin $\mu$

\begin{tabular}{|l|c|c|c|}
\cline { 2 - 3 } \multicolumn{1}{c|}{ Input: $t e$} & DEP IO C & DEP IO V & FOOTMIN $\mu$ \\
\hline a. $(t e ́)$ & & & $*$ \\
\hline b. $(t e ́ e)$ & & e! & \\
\hline c. $($ téte $)$ & $\mathrm{t} !$ & $\mathrm{e} !$ & \\
\hline
\end{tabular}

The next section explores Spanish main stress assignment in non-verbs and concludes that Spanish also accepts monosyllabic bimoraic feet.

\section{Moraic minimal foot in Spanish regular non-verbal main stress assignment}

According to the principles of regular non-verbal stress assignment accepted by many linguists, summarized below, the minimal foot in Spanish is bimoraic ${ }^{3}$.

(10) Spanish regular non-verbal stress assignment

a. Final heavy syllables form a monosyllabic bimoraic foot, i.e., $m e(l o ́ n)_{\mathrm{Ft}}$ 'melon', $\operatorname{pen}(\text { dón })_{\mathrm{Ft}}$ 'slut'

\footnotetext{
${ }^{3}$ Among others, Harris (1983, 1992, 1995); Den Os and Kager (1986); Dunlap (1991); Morales Front (1994); Rosenthall (1994); D’Introno et al (1995); Eddington (2000); Piñeros (2001); Bárkányi (2002a, b); Alvord (2003); Face (2004).
} 
b. Final light syllables form a disyllabic trochaic foot with the preceding syllable, i.e., pre(sénte) $)_{\mathrm{Ft}}$ 'present', computa(dóra) $)_{\mathrm{Ft}}$ 'computer'

c. According to the previous generalizations the possible regular feet in Spanish are $\left(\sigma^{\prime} \mathrm{L}\right)$ and $\left(H^{\prime}\right)$, where $\sigma$ stands for any stressed syllable, regardless of weight, $\mathrm{L}$ for a light syllable and $\mathrm{H}$ for a heavy syllable.

The OT formalization of the previous generalizations requires FOOTMIN $\sigma$ be outranked. First, the ranking of TrocheE and FoOTMin $\mu$ over FoOtMino ensures the emergence of a monosyllabic bimoraic candidate, even if it violates syllable binarity.

(11) Trochee, FootMin $\mu$ » FootMin $\sigma$

TrOCheE(a. k. a. RHTYPE = T, Kager, 1999: 172): feet have initial prominence. (One ${ }^{\star}$ for every iambic foot).

(12) Trochee, FootMin $\mu$ » FootMino

\begin{tabular}{|c|c|c|c|c|}
\hline \multicolumn{2}{|r|}{ Input: melón } & TROCHEE & FоOтMіN $\mu$ & FоOTMiñ \\
\hline$\sqrt{\sigma}$ & a. me(lón) & & & $*$ \\
\hline & b. (melón) & *! & & \\
\hline & c. (me)lón & & $* !$ & \\
\hline
\end{tabular}

The candidate $c$ (mé)lon would also be ruled out by highly ranked WSP and AFR. AFR prevents a heavy penultimate syllable to form a monosyllabic foot, whereas the action of both constraints guarantees a heavy stressed ultimate or penultimate syllable.

(13) WSP, AFR » FOOTMINo

a. WSP: (Kager 1999: 155): heavy syllables are stressed. (One * for every heavy unstressed syllable).

b. AFR (Align (FOOT, Right, PRWD, Right), Kager, 1999: 163): every foot stands at the right edge of the PrWd. (One * per segment between the right edge of a foot and the right edge of the PrWd

(14) WSP, AFR „ FOOTMINo

\begin{tabular}{|l|c|c|c|}
\cline { 2 - 4 } \multicolumn{1}{c|}{ Input: presente } & WSP & AFR & FоOTMINo \\
\hline a. $p r e(\operatorname{sénte)}$ & & & \\
\hline b. $p r e s e n(t e ́)$ & $* !$ & & $*$ \\
\hline c. $p r e(\operatorname{sé} n) t e$ & & $t ! e$ & $*$ \\
\hline
\end{tabular}

(15) WSP, AFR » FOOTMINo

\begin{tabular}{|l|c|c|c|}
\cline { 2 - 4 } \multicolumn{1}{c|}{ Input: pedón } & WSP & AFR & FoOTMINo \\
\hline \multirow{2}{*}{ a.pen(dón) } & & & $*$ \\
\hline
\end{tabular}




\begin{tabular}{|c|c|c|c|}
\hline b. $($ pen)dón & $* !$ & d!on & $*$ \\
\hline c. (pendón) & $* !$ & e! & \\
\hline
\end{tabular}

The next section outlines some Spanish productive truncatory patterns and concludes that the shape of Spanish truncated words is minimally bimoraic, the size of the minimal word/foot in the same language ${ }^{4}$.

\section{Major Spanish truncatory patterns}

Truncation is the process in which a source word or base, usually a noun or adjective, is shortened not in an arbitrary way, but to conform to a process specific shape target. In Spanish we find truncation patterns where segmental material from the edges of some prosodic words is removed, producing typically disyllabic paroxytone truncated words, as in, $(\text { Trunc. }=\text { Truncated form }, \ldots=\text { at least one syllable })^{5}$. In this study, truncated words that omit segmental material from the right and left edges of a base word will be referred to as Type A and B respectively, as seen in examples a-b below. ${ }^{6}$

(16) Truncation patterns

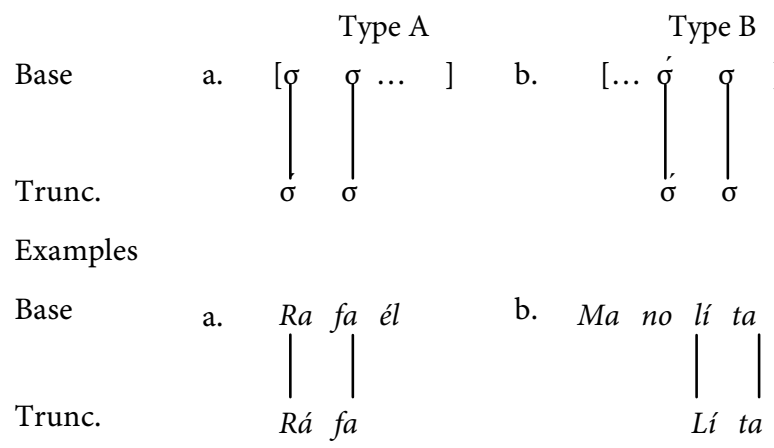

\footnotetext{
${ }^{4}$ This pattern seems to coincide with Spanish ancestor Latin. According to the data in Biville (1989), Latin truncated hypocoristics are normally two syllables long, e.g., Aphro < Aphrodita. However, the few monosyllabic nicknames attested are bimoraic, e.g., Pól < Poledépol.

${ }^{5}$ See Feliu (2001) for a trisyllabic truncation pattern.

It is unusual, but we can find a handful of examples of Spanish truncated hypocoristics that omit segmental material from both edges: Elizabéth > Líz, Fernándo > Nán, Hipólito > Póli, Pólo. The minimal size of these examples seems to be bimoraic.

${ }^{6}$ Segmental changes in the syllabic onset are not dealt with in this study since they do not affect syllabic weight.
} 


\subsection{Type A}

The majority of Type A truncated words are disyllabic. Canonical penultimate stress is displayed in the abbreviated form. Examples of hypocoristics include Rafaél $>$ Ráfa, Alejándro > Álex, Javiér > Jávi, Francísco > Fráncis. This process occurs in common nouns such as bicicléta $>$ bíci 'bicycle', profesór $>$ prófe 'professor', motocicléta $>$ móto 'motorcycle', película > péli 'film', or in the adjective divertído > diver 'fun'.

The second major Type A truncation pattern found in Spanish coincides with its Type B counterpart and includes monosyllabic bimoraic truncated words, which normally keep the leftmost edge of their source. The study of the Spanish hypocoristic data found in Boyd Bowman (1955), van Wijk (1964), Urawa (1985), Hoffman (1969), Costenla Umaña (1982), Casado Velarde (1984, 1999), Albaigés Olivart (1984, 1995), Fajardo (1990), Hamans (1996) and Roca \& Felíu (2003a) brings into light too many examples to ignore

(17) Type A monosyllabic bimoraic examples

$$
\begin{aligned}
& \text { Albérto }>\text { Ál Cristína }>\text { Crís Fermína }>\text { Fér } \quad \text { Gustávo }>\text { Gús Orlándo }>\text { Ór } \\
& \text { Alfónso }>A \text { Al Crístina }>\text { Críst Fernándo }>\text { Fér Jórge }>\text { Jór Paulína }>\text { Páu } \\
& \text { Artúro }>A \text { Ar Cristóbal }>\text { Crís Francísca }>\text { Frán Nélson }>\text { Nél Raymúndo }>\text { Ráy } \\
& \text { Bárbara }>\text { Bár Édgar }>E \text { Éd Francísco }>\text { Frán Norbérto }>\text { Nór } \\
& \text { Costánza }>\text { Cós Eugénia }>\text { Éu Gilbérto }>\text { Gíl Norbérto }>\text { Nóy }
\end{aligned}
$$

There seems to be a difference between the creation of truncated hypocoristics and the truncation of common nouns, in which monosyllabic truncated forms are very unusual. Some exceptions, which may receive a morphological explanation, are: exmarido 'ex-husband' / exmujer 'ex-wife' / exnovio, -a 'ex-boyfriend', 'ex-girlfriend' > ex. Other examples are: propagánda > próp 'propaganda', publicidád > púb 'commercial break'.

Spanish generally disfavors Type A monosyllabic truncated words ending in a vowel. Examples are scarce; the study of the Latin American and Spanish hypocoristic data in Boyd Bowman (1955), van Wijk (1964), Urawa (1985), Hoffman (1969), Costenla Umaña (1982), Casado Velarde (1984, 1999), Albaigés Olivert (1984, 1995) Fajardo (1990), Hamans (1996) and Roca \& Felíu (2003a) only yields a handful of examples: Clé $<$ Clementína, Dí < Diána, Fló < Florencio, -a, Sú < Susána, Ró > Rocío, Pe $<$ Penélope. This asymmetry (bimoraic but not monomoraic monosyllabic truncated words are possible) supported by the observation of the data so far, suggests that only truncated words that adhere to the minimal bimoraic word-size requirement are possible. 


\subsection{Type B}

In Type B truncated words, the stressed syllable of the base and the final unstressed syllable, in paroxytone base words, are kept. In other words, according to the principles of regular non-verbal stress assignment previously outlined, Type B truncated words discard material not contained within the main stressed foot.

In the following chart, example $a$ displays paroxytone-based Type B truncation, whereas example $b$ exhibits the truncation of a monosyllabic foot in oxytone base words.

(18) Spanish Type B truncation
Base
a. $\left.\begin{array}{rllll}{[\ldots} & ( & \sigma^{\prime} & f & )_{\mathrm{Ft}}\end{array}\right]$
b. $\left.\quad\left[\ldots \quad\left(\left.\right|_{\mathrm{H}} ^{\mathrm{H}}\right)_{\mathrm{Ft}}\right)_{\mathrm{Ft}}\right]$
Trunc.
Examples

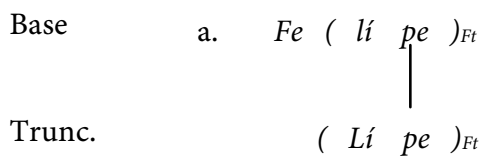
b. Je $\left(\left.\right|_{(\text {sús })_{F t}}\right.$

There is dialectal variation in truncated hypocoristics obtained from bases with an oxytone stress. Peninsular Spanish generally retains the last stressed closed syllable of the base in the truncated form. The stressed syllable in the truncated word matches the stressed syllable in the base in all dialects. On the other hand, some Latin American Spanish dialects may add an epenthetic gender marking ending ( $-o$ or $-a)$, as seen in below, to some truncated hypocoristics formed from oxytone bases ending in a consonant?.

(19) Latin American Spanish

Model
Base
Trunc.

Example

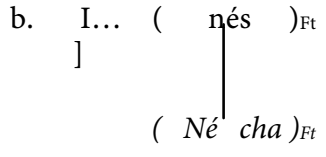

\footnotetext{
${ }^{7}$ It must be noticed that all these hypocoristics are attested in Peninsular Spanish as well
} 
The addition of an extra vowel affects the prosodic structure of the truncated form by adding an extra syllable that is not present in the source. More examples of this pattern are the following: Joaquín > Quino, Isabél > Béla, Valentín > Tíno, Jesús > Súso, Ramón > Móncho.

Piñeros (2002) notes this variation among Spanish dialects regarding monosyllabic Type B truncated words and proposes the use of two optimality theoretical coda condition constraints (CODACOND), a "strict" version that bans any coda with any point of articulation and a "relaxed" version, which allows coronal codas to surface. Piñeros suggests that the dialects in which the strict version of CODACOND dominates, an epenthetic vowel is inserted, thus forming a disyllabic truncated word $($ Tín $<0>)$. Conversely, in the dialects that allow monosyllabic truncated words, the relaxed CODACOND constraint prevails.

Roca and Felíu (2003a, 2003b) reject Piñeros' phonological analysis and the use of relaxed CODACOND constraint for different reasons. First, the constraint is ad-hoc, motivated only to take care of the epenthetic vowel in truncates. Second, Piñeros' analysis does not explain cases in which the final vowel changes: Matílde > Tíla, Silvéstre > Véto. The same authors claim morphology plays a decisive role in the shaping of Spanish truncated words. First, the usual epenthetic vowel in Spanish is $e$. Second, the selected epenthetic vowel seems to coincide with the masculine or feminine gender desinence: $a$ for feminine names and $o$ for masculine names. For instance, considering the examples seen above, Joaquín > Quíno are male names and Isabél > Béla are feminine names. Therefore, the masculine desinence $-o$ is assigned to the former and the feminine desinence $-a$ is asigned to the latter. According to Felíu and Roca, the desinences are not present in the base form since they are lexically marked desinenceless.

More Type B examples displaying paroxytone stress include the following: Ernestina $>$ Tína, Enriquéta > Quéta, Manolíta > Lita, Teodóra > Dóra. On the other hand, there are a considerable number of oxytone-based Type B truncation examples:

(20) Type B monosyllabic bimoraic examples

$\begin{array}{lllll}\text { Abigáil }>\text { Gáil } & \text { Concepción }>\text { Chón } & \text { Froilán }>\text { Lán } & \text { Manuél }>\text { Mél } & \text { Samuél > Mél } \\ \text { Agustín }>\text { Tín } & \text { Daniél }>\text { Nél } & \text { Hernán }>\text { Nán } & \text { Martín }>\text { Tín } & \text { Sebastián }>\text { Tán } \\ \text { Anáis }>\text { Náis } & \text { Delfín }>\text { Fín } & \text { Inés }>\text { Nésh } & \text { Moisés }>\text { Chés } & \text { Sebastián }>\text { Tián } \\ \text { Ascensión }>\text { Chón } & \text { Efraín }>\text { Pín } & \text { Isabél }>\text { Bél } & \text { Montserrát }>\text { Rát } & \text { Senén }>\text { Nén } \\ \text { Asunción }>\text { Chón } & \text { Efrén }>\text { Frén } & \text { Ismaél }>\text { Mél } & \text { Omár }>\text { Már } & \text { Tomás }>\text { Más } \\ \text { Babét }>\text { Bét } & \text { Elisabét }>\text { Bét } & \text { Jesús }>\text { Chús } & \text { Pantaleón }>\text { Lón } & \text { Valentín }>\text { Tín } \\ \text { Beatríz }>\text { Tíz } & \text { Encarnación }>\text { Chón } \text { Joaquín }>\text { Quín } & \text { Rafaél }>\text { Fáy } & \end{array}$




$\begin{array}{llll}\text { Beatríz }>\text { Tísh } & \text { Estér }>\text { Téy } & \text { Leonór }>\text { Nóy } & \text { Ramón }>\text { Món } \\ \text { Benjamín }>\text { Mín } & \text { Fermín }>\text { Mín } & \text { Marilín }>\text { Lín } & \text { Salomón }>\text { Món }\end{array}$

Notice that all the previous examples are hypocoristics. There are very few examples of Type B truncated common nouns attested: autobús > bús 'bus', compañéro > néro 'mate', chiquíllo, -a > quíllo, -a 'boy/girl.

\subsection{OT analysis}

The following chart displays a summary of the Spanish truncatory patterns discussed in the previous section:

(21) Spanish truncatory processes and shapes

$\begin{array}{lll} & \text { Type A } & \text { Type B } \\ \text { Disyllabic } & \text { Fernándo }>\text { Férnan } & \text { Enriquéta }>\text { Quéta } \\ \text { Monosyllabic } & & \\ \text { a. Bimoraic } & \text { Fernándo }>\text { Fér } & \text { Valentín }>\text { Tín } \\ \text { b. Monomoraic } & - & -\end{array}$

Type A truncated words yield both monosyllabic and disyllabic truncated results (e.g., Frán < Francísco, Ráfa < Rafaél). The minimal word/foot size requirements play the role of allowing both types of feet to surface. The stressed syllable invariantly conforms to the trochaic pattern. This analysis explains why closed but not open syllables can constitute a truncated word in Spanish. The size of an open monomoraic syllable does not adhere to the minimal word, and foot, requirements, which is the reason why it almost never surfaces.

(22) Spanish Type A truncation

Base Form

Fernándo
a. Monosyllabic (bimoraic) truncated form:
Fér ${ }^{*} F e ́$
b. Disyllabic truncated form:
Férnan

As supported previously, oxytone words ending in a heavy syllable form a monosyllabic bimoraic foot, whereas a final light syllable forms a disyllabic trochaic foot with the previous syllable. Therefore, Type B hypocoristics such as Nór $<$ Leo (nór) Ft $_{\mathrm{Ft}}$ and disyllabic Type $\mathrm{B}$ forms, e.g., Tína $<$ Ernes $(\text { tina })_{\mathrm{Ft}}$, also truncate the main foot of the source, conforming to the original trochaic pattern (Piñeros, 1998, 2000a, 2000b, 2002). 
(23) Spanish Type B truncation

$\begin{array}{lll}\text { Base Form } & \text { Main foot } & \text { Type B Truncated form } \\ \text { a. Final bimoraic syllable } & \text { Leo (nór)Ft } & \text { Nór } \\ \text { b. Final monomoraic syllable } & \text { Ernes (tína)Ft } & \text { Tína }\end{array}$

This model just outlined differs from other studies. Before the work of Piñeros $(1998,2000 a, 2000 b, 2002)$ there was consensus among the different linguists who analyzed Spanish truncatory morphology. They all agreed in considering that the template to which Spanish truncated words conform was disyllabic. Weeda (1992) analyzed Types A and B truncated forms in Costa Rican Spanish and concludes that their template is a syllabic trochee. Prieto i vives (1992) and Lipski (1995) offered a templatic analysis that relied on prosodic circumscription (McCarthy and Prince 1990, 1993, 1995a, Lombardi and McCarthy 1991) and templatic morphology to account for the data. Colina (1996), based on Prieto i Vives' (1992) Type A data also supports a disyllabic trochaic template and analyze the data from an optimality theoretic standpoint.

On the other hand, Piñeros $(1998,2000 a, 2000 b, 2002)$ support a trochaic (bimoraic or disyllabic) template and analyze the data from an optimality theoretic standpoint. For instance, Piñeros (2002) offers an optimality theoretic analysis of mainly Type B truncatory process in Spanish that relies on the ranking of different constraints to obtain binary trochaic truncated words. For his analysis, Piñeros (2002) follows Benua (1995) in applying some truncation-specific correspondence constraints. In Piñeros' (2002) analysis, the undominated hierarchy FOOTBIN, PARSE- $\sigma$ ALIGN-FT-R (also known as RESTRICTOR, responsible for delimiting or "restricting" the size of the prosodic word, McCarthy and Prince 1995) is responsible for a prosodic word of exactly two syllables or two moras long in Spanish. On the other hand, foot-sensitive Type B truncation is treated in a different manner. Piñeros assumes a constraint MAX FT BT that in the output form preserves the integrity of the foot already present in the base.

The effects of the Restrictor hierarchy, FOOTBIn, PARSE- $\sigma$, ALIGN-FT-R, are exemplified next with the input bicicléta 'bicycle' and its Type A truncated word bicis.

(24) Restrictor constraints (Piñeros, 2002: 442)

a. FoOtBin (PIE-BINARIO in Piñeros' article): metrical feet are binary at a moraic or syllabic analysis.

\footnotetext{
${ }^{8}$ This ranking exemplifies the effects of RESTRICTOR constraints only. Any disyllabic candidate would win. Further analyses are needed to obtain the right optimal candidate.
} 
b. PARSE- $\sigma$ (AFILIAR- $\sigma$ ): syllables are parsed into feet.

c. Align-Ft-R (Alinear(PIE)): the right edge of a foot coincides with the right edge of a prosodic word.

(25) FootBin, PARse- $\sigma$, Align-FT-R (Piñeros 2002: 442)

\begin{tabular}{|l|c|c|c|}
\cline { 2 - 4 } \multicolumn{1}{c|}{ Base: bicicleta } & FOOTBIN & PARSE- $\sigma$ & ALIGN-FT-R \\
\hline a. $($ bici) (cleta) & & & (bici)! \\
\hline b. $($ bi) (ciclé) & & $b i !$ & \\
\hline c. $($ bici) & & & \\
\hline d. $(b i)$ & $\star !$ & & \\
\hline
\end{tabular}

The only possible prosodic word resulting from the RESTRICTOR filter is, then, disyllabic or bimoraic. Align-FT-R rejects candidates consisting of more than one foot, Parse- $\sigma$ filters out candidates with unparsed material and FOOTBIN is responsible for eliminating candidates with feet that are too small or too big. The winning candidate is obtained at the cost of violating MAX BT SEG, as some segmental material from the base is erased after truncation takes place. For this reason, Piñeros states that truncation needs MAX BT SEG to be outranked by RESTRICTOR (citing Benua, 1995). As expected by the previous ranking, the analysis of bases starting with a heavy syllable adequately predicts the emergence of either a monosyllabic bimoraic or a disyllabic truncate.

(26) FootBin, PARSE- $\sigma$, Align-FT-R (Piñeros, 2002: 442)

\begin{tabular}{|l|c|c|c|}
\cline { 2 - 4 } \multicolumn{1}{c|}{ Base: Raymúndo } & FOOTBIN & PARSE- $\sigma$ & ALIGN-FT-R \\
\hline a. (Ray) (múndo) & & & (múndo)! \\
\hline b. Ray (múndo) & & Ray! & \\
\hline c. (Ráy) & & & \\
\hline d. (Ráymun) & & & \\
\hline
\end{tabular}

In addition, Piñeros notes that the observation that all truncated words are trochaic implies that the Trochee constraint is undominated.

(27) Additional constraints in Piñeros' (2002) analysis

a. MAX BT SEG (MAX): every segment in the (B)ase has a correspondent in the (T)runcated form

b. Trochee (TROQUeO): every foot is left prominent

The resulting ranking TROCHEE, RESTRICTOR » MAX BT SEG is put to the test in the following tableau with an input colégio 'school' and its Type A truncated word cóle. 
(28) Trochee, Restrictor» MAX BT Seg (Piñeros, 2002: 443)

\begin{tabular}{|l|c|c|c|}
\cline { 2 - 4 } \multicolumn{1}{l|}{ Base: colégio } & TROCHEE & RESTRICTOR & MAX BT SEG \\
\hline a. co(légio) & & co! (PARSE- $\sigma)$ & \\
\hline b. (cóle) & & & gio \\
\hline c. (colé) & $* !$ & & gio \\
\hline d. (có) & & $* !$ & legio \\
\hline
\end{tabular}

In accord with the ranking in, the resulting prosodic word is a moraic syllabic TROCHEE. Trochee rejects disyllabic candidate $c$. However, when analyzing bases with a heavy initial syllable, the previous ranking does inadequately predict the emergence of only a disyllabic candidate. MAX BT Seg imposes a preference for longer truncates, thus disallowing monosyllabic attested truncated words such as Ráy, as seen in the following tableau.

(29) Trochee, Restrictor» MAX BT Seg (Piñeros, 2002: 443)

\begin{tabular}{|l|c|c|c|}
\cline { 2 - 4 } \multicolumn{1}{c|}{ Base: Raymúndo } & TROCHEE & RESTRICTOR & MAX BT SEG \\
\hline a. (Ray) & & & mun do! \\
\hline b. (Ráymun) & & & $d o$ \\
\hline c. (Raymún) & $* !$ & & $d o$ \\
\hline
\end{tabular}

The analysis proposed in this essay attempts to correct Piñeros' inadequacy just outlined above. In addition, it provides a coherent OT formalization of the data, including word minimality and stress assignment. As previously explored, this study supports the hypothesis that the minimal size of not only the foot and the word, but also the truncated word is bimoraic. An OT formalization in line with the previous analyses on word minimality and stress assignment occupies the rest of this section.

The ranking of ALL FEET LeFT (AFL) and AlL FEET Right (AFR) over MAX BT Seg determines the preference for hypocoristics to form only one foot, as seen in the next tableau. The winning truncated candidate necessarily violates MAX BT SEG.

(30) AFR, AFL » MAX BT SEG

a. AFR (Align (FoOT, Right, PRWD, Right), Kager, 1999: 163): every foot stands at the right edge of the PrWd. (One* per segment between the right edge of a foot and the right edge of the PrWd).

b. AFL (ALIGN (FOOT, LEFT, PRWD, LEFT), Kager, 1999: 163): every foot stands at the left edge of the PrWd. (One * per segment between the left edge of a foot and the left edge of the PrWd). 
c. MAX BT SEG (Benua, 1995: 80): every segment in the base has a correspondent in the truncated form. (One ${ }^{*}$ per deleted element).

(31) AFR, AFL » MAX BT SEG

\begin{tabular}{|l|c|c|c|}
\cline { 2 - 4 } \multicolumn{1}{c|}{ Base: Enriqueta } & AFR & AFL & MAX BT SEG \\
\hline a. (Queta) & & & en ri \\
\hline b. Enri (quéta) & & en!ri & \\
\hline c. (Enri) (quéta) & que!ta & en!ri & \\
\hline
\end{tabular}

The previous ranking partially establishes the preference for Spanish truncated forms to form a single foot, eliminating unparsed syllables or secondary feet, at the cost of minimally violating BT Maximality. Furthermore, MAX BT SEG is ranked below FoOTMAX $\mu$ to prevent the surfacing of a candidate that forms a long foot, as in the next tableau.

(32) FоотMAX $\mu$ : feet are maximally bimoraic. (One ${ }^{*}$ for every mora in excess of two in a foot).

(33) FOOTMAX $\mu$ » MAX BT SEG

\begin{tabular}{|l|c|c|}
\cline { 2 - 3 } \multicolumn{1}{c|}{ Base: Enriqueta } & FоотMAX $\mu$ & MAX BT SEG \\
\hline a. (Queta) & & en $r i$ \\
\hline b. (Enriquéta) & ${ }^{*}$ !** & \\
\hline c. (Riquéta) & $\star !$ & en \\
\hline
\end{tabular}

Type B hypocoristics discard the segmental material to the left of the main foot of the base. This generality is partially captured by highly ranked HEADMATCH, which preserves the head of the main foot from the base in the truncated form, over MAX BT SEG.

(34) HeadMatch » MAX BT SeG

HeAdMatch (McCarthy, 2000: 183): if $\alpha$ is in $\mathrm{H}^{\prime}(\operatorname{PrWd})$ and $\alpha \Re \beta$, then $\beta$ is in $\mathrm{H}^{\prime}(\operatorname{PrWd})$. (One * for every segment between the head of PrWd in B and the head of PrWd in T)

HEADMATCH ensures the head of the base form is the same in the truncated form, as in the next tableau. ${ }^{9}$

\footnotetext{
9 An additional candidate ${ }^{*}$ Riqué, which adheres to HEADMATCH, is banned by highly ranked TrocheE.
} 
(35) HeAdMATCH » MAX BT SEG

\begin{tabular}{|l|c|c|}
\cline { 2 - 3 } \multicolumn{1}{c|}{ Base: Enriqueta } & FоOтMAX $\mu$ & MAX BT SEG \\
\hline a. Queta & & en $r i$ \\
\hline b. Ríque & qu!e & en \\
\hline c. Énri & n!rique & que \\
\hline
\end{tabular}

Type B nicknames ending in a heavy stressed syllable only keep the stressed monosyllabic foot from the base form, thus violating FoOTMino, e.g., Tín < Valentín. A possible candidate Léntin, which respects foot binarity without having to epenthesize any segments, is banned by HEADMATCH.

(36) HEADMATCH » FOOTMino

\begin{tabular}{|l|c|c|}
\cline { 2 - 3 } \multicolumn{1}{c|}{ Base: Valentín } & HeADMATCH & FoOTMino \\
\hline a. Tín & & $*$ \\
\hline b. Léntin & $!^{\star}$ & \\
\hline
\end{tabular}

In addition to this ranking, TROCHEE » IAMB prevents disyllabic iambic hypocoristics from appearing, e.g., ${ }^{\star}$ Lentín. Given the results of the previous rankings, no segments to the left of the stressed syllable in the base are maintained in the Type B truncated form in Spanish.

Type B nicknames ending in a heavy stressed syllable do not keep only the rightmost foot in some Latin American Spanish dialects, as candidate b shows in the tableau below. Instead, some segmental material is epenthesized to comply with foot syllable minimalism.

(37) DEP BT SEG: (Benua, 1995: 80): every segment in the truncated form has a correspondent in the base. (One ${ }^{\star}$ for each epenthetic segment).

(38) FoOTMINo » DEP BT SEG

\begin{tabular}{|l|c|c|}
\cline { 2 - 3 } \multicolumn{1}{c|}{ Base: Valentín } & FOоTMINo & DEP BT SEG \\
\hline a. Tíno & & $o$ \\
\hline b. Tín & $!^{*}$ & \\
\hline
\end{tabular}

On the other hand, for Spanish dialects that do not need to epenthesize any segments to comply with syllable minimalism DEP BT SEG outranks FOOTMINo, allowing a monosyllabic bimoraic nickname. 
(39) DeP BT SEG » FoOTMino

\begin{tabular}{|l|c|c|}
\cline { 2 - 3 } \multicolumn{1}{c|}{ Base: Valentín } & DEP BT SEG & FoOTMINo \\
\hline a. Tín & & $*$ \\
\hline b. Tíno & $o !$ & \\
\hline
\end{tabular}

ALIGN HEAD RIGHT and FOOTMINo are not strictly ranked with one another; in some instances, ALIGN HEAD Right dominates FOOTMINo producing monosyllabic results and in other cases, the ranking is reversed, yielding the more productive foot sensitive results, contradicting the OT principle of strict domination. Strict domination is one of the main principles in OT, which states that a constraint $\mathrm{C} 1$ can be ranked with another constraint $\mathrm{C} 2$ in two ways: either $\mathrm{C} 1 » \mathrm{C} 2$ or $\mathrm{C} 2$ » $\mathrm{C} 1$. $\mathrm{C} 2, \mathrm{C} 1$ occurs when no empirical data supports either ranking.

The issue of variation has not been dealt with satisfactorily in OT. Different approaches have been put forward within OT to answer to variation. One way to analyze variation in OT is to posit co-phonologies (among others, Inkelas and Orgun, 1995), or different constraint rerankings within one grammar, where each co-phonology selects a different output.

(40) Co-phonologies

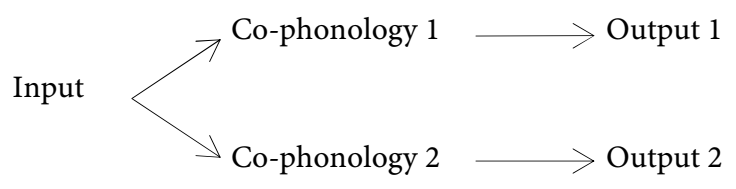

According to Kager (1999: 405), this approach has the disadvantage of predicting that each co-phonology is independent from one another, allowing co-phonologies to produce very different outputs. Kager concludes that this prediction is inadequate as candidates in variation are usually similar.

Free ranking of constraints (Anttila, 1997, Anttila and Cho, 1998) is another solution to variation in OT. When two constraints are freely ranked, the evaluation branches in two directions: in one branch, $\mathrm{C} 1 » \mathrm{C} 2$ and in the other branch, C2 » $\mathrm{C} 1$. Kager (1999: 406) offers a formal definition of free ranking, copied here:

(41) Interpretation of free ranking of constraints C1, C2

Evaluation of the candidate set is split into two subhierarchies, each of which selects an optimal output. One subhierarchy has $\mathrm{C} 1 » \mathrm{C} 2$ and the other $\mathrm{C} 2 » \mathrm{C} 1$. 
The principle of strict domination is preserved under free ranking in each subhierarchy. On the other hand, Kager (1999: 407) notes that the main disadvantage of free ranking is that it is not clear whether free ranking grammars are learnable or not.

Back to truncation, the same constraint ranking responsible for Type B truncates is active in Type A.

(42) AFR AFL » MAX BT SEG

\begin{tabular}{|l|l|l|c|}
\cline { 2 - 3 } \multicolumn{1}{c|}{ Base: Saturníno } & AFR & AFL & MAX BT SEG \\
\hline a. Sátur & & & nino \\
\hline b. (Sátur) nino & ni!no & & \\
\hline c. (Sátur) (nino) & ni!no & sa!tur & \\
\hline
\end{tabular}

As in Type B, Type A truncated forms only build one foot due to the action of highly ranked constraints AFR/L over MAX BT SEG. Unparsed syllables or additional feet are not allowed. The winning candidate a minimally violates MAX BT SEG. Another coincident ranking is FоOтMAX $\mu$ » MAX BT Segwhich avoids the surfacing of long footed words such as *(Saturníno) complying with MAX BT SEG. Additionally, the ranking TROCHEE » Iamb is active to ensure the occurrence of trochaic feet.

Highly ranked anchoring constraints are crucial for Type A truncation. ANCHOR BT Ldominates ANCHOR BT R to preserve the left edge of the base form, as shown in the tableau below.

(43) ANCHOR BT R » ANCHOR BT L

ANCHOR BT R/L (McCarthy and Prince, 1995: 123): Any element at the right/left periphery of $B$ has a correspondent at the right/left periphery of $T$. (One ${ }^{*}$ per any epenthesized or erased segment).

(44) Anchor BT L » Anchor BT R

\begin{tabular}{|l|c|c|}
\cline { 2 - 3 } \multicolumn{1}{c|}{ Base: Saturníno } & ANCHOR BT L & ANCHOR BT R \\
\hline a. Sátur & & nino \\
\hline b. Níno & s!atur & \\
\hline c. Túrni & s!a & \\
\hline
\end{tabular}

The previous ranking allows truncated forms to keep the segmental material to the left edge of the prosodic word.

Contrary to Type B truncated words, the winning candidate in the previous tableaux, Sátur, forms a disyllabic foot that does not preserve the right-aligned stress in 
the base form. For this reason, highly ranked HEADMATCH is outranked by TROCHEE and ANCHOR BT L, as in the tableau below.

(45) ANCHOR BT L, TrocheE » HeAdMATCH

The following tableau exemplifies the effects of this ranking.

(46) ANCHOR BT L, TROCHEE » HEADMATCH

\begin{tabular}{|l|c|c|c|}
\cline { 2 - 4 } \multicolumn{1}{c|}{ Base: Saturníno } & ANCHOR BT L & TROCHEE & HEADMATCH \\
\hline a. Sátur & & & tur \\
\hline b. Saní & & $\star !$ & \\
\hline c. Turní & $s ! a$ & $\star !$ & \\
\hline
\end{tabular}

Candidate $b$ conforms to ANCHOR BT L by keeping the first syllable of the base and to HEADMATCH by adding the head in the base. However, the result is an iambic foot, penalized by Trochee.

The optimal candidate Sátur departs from Type A stress assignment and Type B truncation by not complying with highly ranked WSP, a constraint that does not allow unstressed heavy syllables. In Type A truncation, as the result of TETU, respecting the syllable constituency of the base prevails over general foot-wellformedness considerations ${ }^{10}$. To account for this behavior, this study proposes a constraint WT-IDENT BT $\sigma$, modified from Wt-Ident BT, previously described in Kager (1999), which penalizes shortening or lengthening of vowels from input to output and also applies to syllables, preventing BT syllable shortening, e.g., Sátur $>{ }^{\star}$ Sátu, to observe WSP.

(47) WT-IDENT BT $\sigma »$ WSP

WT-IDENT BT $\sigma$ (modified from Kager, 1999: 269): if $\alpha \in$ Domain ( $f$ ); If $\alpha$ is monomoraic, then $f(\alpha)$ is monomoraic; If $\alpha$ is bimoraic, then $f(\alpha)$ is bimoraic. (One ${ }^{\star}$ for every shortened or lengthened syllable in the truncated form).

The next tableau displays the effects of the previous ranking and establishes the preference for a nickname Sátur, even if it disobeys WSP.

\footnotetext{
${ }^{10}$ Nevertheless, notice that Spanish present unpredictable variation in truncated forms ending in a consonant. These final consonants are optional in some Spanish forms, e.g., Spanish Ródol $\sim$ Ródo < Rodólfo. Final consonants are either left behind, as in Máti<Matílde, or they are obligatorily present, e.g., Róber < Robérto. This unpredictability may be the result of the free ranking of WT-IDENT BT $\sigma$ and WSP.
} 
(48) WT-IDENT BT $\sigma »$ WSP

\begin{tabular}{|l|c|c|}
\cline { 2 - 3 } \multicolumn{1}{l|}{ Base: Saturníno } & WT-IDENT BT $\sigma$ & WSP \\
\hline a. Sátur & & $*$ \\
\hline b. Sátu & $\star !$ & \\
\hline
\end{tabular}

To account for Spanish monosyllabic bimoraic Type A truncatory pattern, the constraint Align Head Right is freely ranked with FOоTMiNo, as in the next tableau.

(49) Align Head Right (Align (HEAd, Right, PRWD, Right)): every prosodic word ends with the head of the main foot. (One ${ }^{\star}$ per syllable between the head of the main foot and the right edge of PrWd)

(50) Trochee, Align Head Right » FootMino

\begin{tabular}{|l|c|c|c|}
\cline { 2 - 4 } \multicolumn{1}{c|}{ Base: Fernándo } & Trochee & Align HeAd Right & FootMino \\
\hline a. Fér & & & $*$ \\
\hline b. Férnan & & nan! & \\
\hline c. Fernán & ${ }^{*} !$ & & \\
\hline
\end{tabular}

The constraint FootMin $\mu$, dominating ALIGN HeAD Right also prevents the existence of monosyllabic monomoraic truncated words in Spanish. In addition, the next tableau motivates the domination of Trochee over Align Head Right. For instance, a name such as Spanish Rafaél can only produce a Type A hypocoristic Ráfa, as FoOTMin $\mu$ bans a potential candidate ${ }^{\star} R a ́$, as seen in the next tableau.

(51) Footmin $\mu$, TrocheE » Align HeAd Right

\begin{tabular}{|l|c|c|c|}
\cline { 2 - 4 } \multicolumn{1}{c|}{ Base: Rafaél } & FoоTMin $\mu$ & TROCHEE & ALIGN HEAD Right \\
\hline a. Ráfa & & & $*$ \\
\hline b. Rá & $* !$ & & \\
\hline c. Rafá & & $* !$ & \\
\hline
\end{tabular}

The previous two tableaux support the observation that Spanish only allows Type A monosyllabic truncated words when the leftmost syllable is heavy: highly ranked FoOTMin $\mu$ only allow monosyllabic bimoraic truncated forms to occur ${ }^{11}$.

\footnotetext{
${ }^{11}$ The possibility of making the leftmost light syllable in the base heavy in the truncated form by lengthening is banned in Spanish by WT-IDENT BT, which prohibits lengthening or shortening of syllables in a BT correspondence.
} 
In sum, the promotion of ALIGN HEAD RIGHT in Spanish explains the surfacing of monosyllabic truncated forms. In Spanish, FootMin $\mu$ is ranked over ALIGN HEAD RIGHT, allowing only monosyllabic bimoraic truncated forms to surface.

\section{Summary of conclusions}

The analysis of Spanish truncation processes provided in this study supported the view that they conform to the moraic word/foot minimum. Type B truncated words copy a version of the main stress foot of the source word. These truncations can be disyllabic or monosyllabic, depending on the stress placement of their source. Paroxytone source words build a disyllabic foot and, thus, yield a disyllabic trochaic truncated form. Oxytone bases form a monosyllabic bimoraic foot that may be preserved in the abbreviated form. On the other hand, Type A truncated words can be disyllabic or monosyllabic, provided they are bimoraic.

Recibido: 02-X-2012

Aceptado: 20-V-2013

\section{References}

Albaigés Olivart, J. M. (1984): Diccionario de nombres de personas. Barcelona, Publicacions i Edicions de la Universitat de Barcelona.

Albaigés Olivart, J. M. (1995): Enciclopedia de los nombres propios. Barcelona, Planeta.

Alvord, S. M. (2003): “The psychological unreality of quantity sensitivity in Spanish: experimental evidence", Southwest Journal of Linguistics, 22 (2), 1-12.

Anttila, A. (1997): "Deriving variation from grammar". In Hinskens, F., R. van der Hout and L. Wetzels (eds.): Change and phonological theory. Amsterdam: John Benjamins, págs. 35-68.

Anttila, A. and Young-mee, Y. C. (1998): "Vatiation and change in Optimality Theory", Lingua, 104, 31-56.

Bárkányi, Z. (2002a): “A fresh look at quantity sensitivity in Spanish”, Linguistics, 40 (2), 375-94.

Bárkányi, Z. (2002b): "Primary stress in Spanish". In Satterfield, T. et al. (eds.): Current issues in Romance languages. Amsterdam: John Benjamins, 17-31.

Benua, L. (1995): "Identity effects in morphological truncation". In Beckman, J., L. Walsh and S. Urbanczyk (eds.): University of Massachusetts occasional papers in Linguistics, 18. Amherst: GLSA, 77-136.

Biville, F. (1989): “Un processus dérivationnel méconnu du Latin: la dérivation par 
troncation", L'information Grammaticale, 42, 15-22.

Boyd-Bowman, P. (1955): "Cómo obra la fonética infantil en la formación de los hipocorísticos”, Nueva Revista de Filología Hispánica, 9, 337-366.

Casado Velarde, M. (1984): “Acortamientos léxicos en español actual”, Iberorromania, 20, 1-8.

Casado Velarde, M. (1999): "Otros procesos morfológicos: acortamientos, formación de siglas y acrónimos”. In Bosque, I. and V. Demonte (eds.): Gramática descriptiva de la lengua española. Madrid, Spain: RAE-Espasa Calpe, 5075-5096.

Colina, S. (1996): "Spanish truncation processes: the emergence of the unmarked", Linguistics, 34, 1199-1218.

Costenla Umaña, A. (1982): "Los hipocorísticos costarricenses”, Estudios de Lingüística Hispánica, B (1), 5-51.

Crowhurst, M. J. (1991): "Minimality and foot structure in metrical phonology and prosodic morphology", Unpublished Ph.D. dissertation. Tucson, Arizona, The University of Arizona. (Distributed by The Indiana University Linguistics Club, Bloomington, 1992).

D'Imperio, M. and S. Rosenthall (1999): "Phonetics and phonology of main stress in Italian", Phonology, 16, 1-28.

D’Introno, F., E. del Teso y R. Weston (1995): Fonética y fonología actual del español. Madrid, Cátedra.

Den Os, E. and R. Kager (1986): "Extrametricality and stress in Spanish and Italian", Lingua, 69, 23-48.

Dunlap, E. (1991): "Issues in the moraic structure of Spanish", Unpublished Ph.D. dissertation. Amherst, Massachusetts, University of Massachusetts.

Eddigton, D. (2000): "Spanish stress assignment within the Analogical Modeling of Language”, Language, 76, 92-109.

Face, T. L. (2004): "Perceiving what isn't there: non-acoustic cues for perceiving Spanish stress". In Face, T. L. (ed.): Laboratory approaches to Spanish phonology. Berlin, Germany: Mouton de Gruyter, 117-141.

Fajardo, A. (1990): “Truncamientos léxicos en español actual”, Lebende Sprachen, 35 (3), 132-133.

Felíu, E. (2001): "Output constraints on two Spanish word-creation processes", Linguistics, 39, 871-891.

Hamans, C. (1996): “A lingo of abbrevs", Lingua Posnaniensis, 38, 69-78.

Hammond, M. (1997): “Optimality Theory and prosody”. In Archangeli, D. and D. T. Langendoen (eds.): Optimality Theory. An overview. Cambridge, MA: Blackwell, 33-59. 
Harris, J. W. (1983): Syllable structure and stress in Spanish. A non-linear analysis. Cambridge, MA, MIT Press.

Harris, J. W. (1992): Spanish stress: The extrametricality issue. Bloomington, IN, Indiana University Linguistics Club.

Harris, J. W. (1995): "Projection and edge marking in the computation of stress in Spanish". In Goldsmith, J. A. (ed.): The handbook of phonological theory. Cambridge, MA, Blackwell, 867-887.

Hoffman, R. J. (1969): “The derivation of Spanish hypocoristics”. In Binnick, R. I. et al. (eds.): Papers from the Fifth Regional Meeting of the Chicago Linguistic. Chicago, IL, University of Chicago Press, 366-373.

Inkelas, S. and C.Orhan Orgun (1995): "Level ordering and economy in the lexical phonology of Turkish”, Language, 71, 763-793.

Kager, R. (1999): Optimality Theory. Cambridge, MA, Cambridge University Press.

Lipski, J. M. (1995): "Spanish hypocoristics: towards a unified prosodic analysis", Hispanic Linguistics, 6-7, 387-434.

Lombardi, L. and J. J. McCarthy (1991): "Prosodic circumscription in Choctaw morphology", Phonology, 8, 37-71.

McCarthy, J. J. (2000): "The prosody of phase in Rotuman", Natural Language and Linguistic Theory, 18, 147-197.

McCarthy, J. J. and A. Prince (1990): "Foot and word in prosodic morphology: the Arabic broken plural", Natural Language and Linguistic Theory, 8, 209-283.

McCarthy, J. J. and A. Prince (1993): "Prosodic morphology I: Constraint interaction and satisfaction", Unpublished Manuscript. Amherst, Massachusetts, University of Massachusetts.

McCarthy, J. J. and A. Prince (1995): "Prosodic morphology". In Goldsmith. J. A. (ed.): The handbook of phonological theory. Cambridge, MA, Blackwell, 318-366.

Morales-Front, A. (1994): "A constraint based approach to Spanish phonology", Unpublished Ph.D. dissertation. Urbana-Champaign, Illinois, University of Illinois.

Piñeros, C. E. (1998): "Prosodic morphology in Spanish: constraint interaction in wordformation", Unpublished Ph.D. dissertation. Columbus, Ohio: The Ohio State University.

Piñeros, C. E. (2000a): "Prosodic and segmental unmarkedness in Spanish truncation", Linguistics, 38, 63-98.

Piñeros, C. E. (2000b): "Foot-sensitive word minimization in Spanish", Probus, 12, 291324.

Piñeros, C. E. (2001): "Vowel weightlessness and stress retraction in Spanish", Unpublished manuscript. Iowa City, Iowa: University of Iowa. 
Piñeros, C. E. (2002): “Truncamientos en español”, Bulletin of Hispanic Studies, 79 (4), 437-459.

Prieto i Vives, P. (1992): "Truncation processes in Spanish", Studies in Linguistic Sciences, 22 (1), 143-158.

Prince, Alan, and Paul Smolensky (1993): "Optimality Theory: Constraint Interaction in Generative Grammar." Unpublished manuscript. Rutgers University and The Johns Hopkins University.

Roca, I. and E. Felíu (2003a): "Morphology in truncation: the role of the Spanish desinence". In Booij, G. and J. van Marle (eds.): Yearbook of morphology 2002. Dordrecht, Germany, Kluwer, 187-243.

Roca, I. and E. Felíu (2003b): "Morphology and Phonology in Spanish word truncation". In Booij, G., J. DeCesaris, A. Ralli and S. Scalise (eds.): Topics in morphology: selected papers from the Third Mediterranean Morphology Meeting (Barcelona, September 20-22, 2001). Barcelona, Spain, IULA, 311-329.

Rosenthall, S. (1994): "Vowel/glide alternation in a theory of constraint interaction", Unpublished Ph.D. dissertation. Amherst, Massachusetts: University of Massachusetts.

Urawa, M. (1985): “Muestra de hipocorísticos en el español bogotano”, Thesaurus, 40, 51-102.

Van Wijk, H. L. A. (1964): “Los hipocorísticos hondureños”, Romanistisches Jahrbuch, $15,302-312$.

Weeda, D. S. (1992): “Word truncation in prosodic morphology", Unpublished Ph. D. dissertation. Austin, Texas: The University of Texas. 